\title{
30 年以上経過した表面処理仕様耐候性鋼橋梁の腐食調査*
}

\author{
境 昌宏**, 長谷部智久***, 美馬大樹 ${ }^{\dagger}$, 西 弘明 ${ }^{\dagger \dagger}$, 小室雅人 ${ }^{\dagger \dagger}$, 岸 徳光 ${ }^{\dagger \dagger}$ \\ ** 室蘭工業大学 もの創造系領域 \\ *** 国土交通省 北海道開発局 小樽開発建設部 \\ †国土交通省 北海道開発局 室蘭開発建設部 \\ $\dagger+$ 独立行政法人土木研究所 寒地土木研究所 \\ †† 室蘭工業大学くらし環境系領域
}

\section{Investigation into Corrosion of Surface Treated Weathering Steel Bridges for More Than 30 Years*}

\author{
Masahiro Sakai**, Tomohisa Hasebe***, Hiroki Mima ${ }^{\dagger}$, Hiroaki Nishi ${ }^{\dagger \dagger}$, \\ Masato Komuro ${ }^{\dagger \dagger}{ }^{\dagger}$ and Norimitsu Kishi ${ }^{\dagger \dagger}{ }^{\dagger}$ \\ * * College of Design and Manufacturing Technology, Muroran Institute of Technology \\ *** Otaru Development and Construction Department, Hokkaido Regional Development Bureau, \\ Ministry of Land, Infrastructure, Transport and Tourism \\ $\dagger$ Muroran Development and Construction Department, Hokkaido Regional Development Bureau, \\ Ministry of Land, Infrastructure, Transport and Tourism \\ $\dagger^{\dagger}$ Civil Engineering Research Institute for Cold Region, Public Works Research Institute \\ $\dagger^{\dagger} \dagger$ College of Environmental Technology, Muroran Institute of Technology
}

\begin{abstract}
In order to investigate the corrosion of surface treated weathering steel bridges constructed more than 30 years ago, we conducted a visual inspection, a measurement of rust and coating thickness, a measurement of ion transfer resistance, cross-sectional observation by the reflected polarized light and EPMA analysis. The rust appearances of 57 points out of 78 were assessed normal by the visual inspection. Imbricate and layer-delaminated rusts were observed at the some ends of the bridge beam from which water used to be leaking. The rank of the rust appearance tends to decrease with an increase in the thickness of rust and coatings. The cross-sectional observation and EPMA analysis revealed that the condensed $\mathrm{Cl}$ existed at the bottom of the anomalous rust, while the optically isotropic layer of protective rust existed at the bottom of the normal rust.
\end{abstract}

Key words : weathering steel bridge, corrosion investigation, surface treatment, thickness of rust and coatings, ion transfer resistance, corrosion potential, EPMA

1. 緒

\section{言}

現在，高度経済成長期に建設された多くの橋梁など道 路ストックの高齢化が進み, 今後疲労や劣化などの損傷 が深刻になることが懸念されており, 損傷が軽微な段階 で補修を行うなどの計画的な道路管理が重要となってい る．橋梁材のうち，耐候性鋼材は無塗装でも優れた防食 性を発揮するため, ライフサイクルコスト低減の観点か ら一定の条件を満足する環境下において広く使用されて いる. 耐候性鋼橋梁は表面処理を施さない裸仕様とさび 安定化処理と呼ばれる表面処理を施した表面処理仕様と に分かれる。このうち，裸仕様の耐候性鋼橋梁に関する 腐食調査事例はこれまでにもいくつかの報告がなされて いる ${ }^{1-3)}$. 一方, 表面処理仕様耐候性鋼橋梁, しかも架設

* 第 58 回材料と環境討論会 $(2011$ 年, 名古屋) で発表

** T050-8585 室蘭市水元町 27-1 (27-1, Mizumoto-cho, Muroran, 050-8585 Japan)

*** $\quad$ T 047-8555 小樽市潮見台 1 丁目 15 番 5 号（1-15-5, Shiomidai, Otaru, 047-8555 Japan)

干 051-8524 室蘭市入江町 1 番地 14 (1-14, Irie-cho, Muroran, 0518524 Japan)

† T062-8602 札幌市豊平区平岸 1 条 3 丁目 1 番 34 号 (Hiragishi, 1-3-1-34, Toyohira-ku, Sapporo, 062-8602 Japan)

† $=050$-8585 室蘭市水元町 27-1 (27-1, Mizumoto-cho, Muroran, 050-8585 Japan)
から 30 年以上経過した表面処理仕様耐候性鋼橋梁に関 する腐食調査の報告事例はこれまでにない。著者らは， 表面処理仕様耐候性鋼橋梁の保守点検, 補修の必要性判 断の一助となることを期待し, 架設から 30 年以上経過 した表面処理仕様耐候性橋梁の腐食調査を実施した。具 体的には, 外観目視調査, さび・被膜厚測定, 断面観察, EPMA 分析などの調查を行ったので，本報告ではその調 査結果について述べる. また, 実橋梁から切り出したサ ンプルの自然浸漬電位測定も行ったので, その結果につ いても報告する。

\section{2. 腐 食 調 查}

\section{1 調查対象耐候性鋼橋梁}

腐食調查を実施した橋梁は室蘭新道を構成する道路橋 である. Fig. 1 にその外観の一例を示す．室蘭新道は札 幌, 室蘭を結ぶ国道 36 号線のうち, 室蘭市内を通過す る延長約 $4.2 \mathrm{~km}$ の自動車専用道路であり, このうち耐候 性鋼材が使用された橋梁延長は約 $2.1 \mathrm{~km}$, 使用された耐 候性鋼材は約 7,800 t である. 室蘭新道の主要部分を構成 する 5 つの橋梁の建設は 1973 年から 1980 年にかけて行 われ，いずれの橋梁も建設から 30 年以上が経過してい る. また, いずれの橋梁も離岸距離 $2 \mathrm{~km}$ 以内の地点に 存在し, 平成 16 年度に行われた飛来塩分量調査では飛

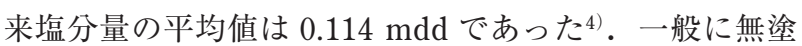




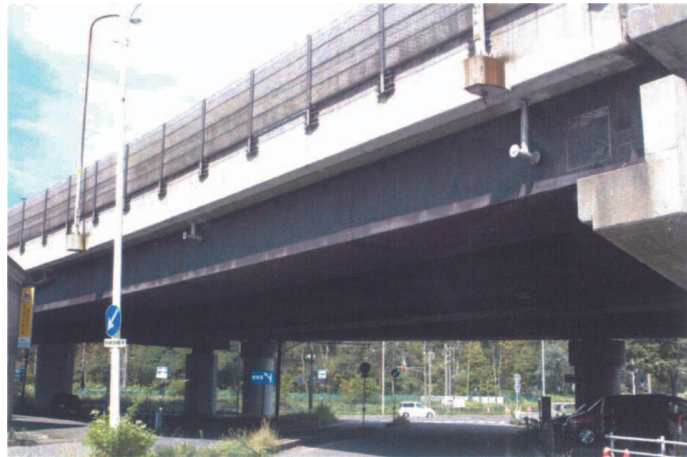

Fig. 1 Appearance of Muroran shin-dou ; Muroran shin-dou is a motorway bridge constructed more than 30 years ago.

装仕様耐候性鋼の適用可能地域は飛来塩分量が $0.05 \mathrm{mdd}$ 以下の地点とされており ${ }^{5)}$, 上記塩分量はその約 2 倍と 高い值を示している．室蘭新道に使用された耐候性鋼材 （JIS G3114 SMA41A, SMA50Aなど）は，リン酸塩/アク リル樹脂複層型処理剂を用いた表面処理が施されてい る.

\section{2 腐食調査内容および調査箇所}

今回の報告では, 現地調査として実施した (1) 外観目 視調査, (2) 電磁膜厚計 ( (株) ケット科学研究所, LZ900J）によるさび・被膜厚測定，（3）イオン透過抵抗測定 装置（日鉄防蝕 (株)，RST(Rust State Tester)) によるイ オン透過抵抗測定の結果について述べる。 また, 室内試 験として, (4) 偏光顕微鏡（（株)ニコン, OPTIPHOT100）によるさび断面観察，（5)EPMA（(株)島津製作所, EPMA-1400) による面分析を行ったので，その結果につ いても報告する。調査箇所は橋梁の桁中間部および端部 とし，箱桁および鈑桁それぞれフランジ，ウェブの代表 的な 78 力所について実施した。ただし，(4)および(5) の調査については 78 力所のうち代表的な数力所につい て実施した。

\section{3 自然浸漬電位測定}

実橋梁から切り出した試験片の自然浸漬電位を $0.1 \mathrm{M}$ $\mathrm{Na}_{2} \mathrm{SO}_{4}$ 溶液中で測定した。比較のため，（1）溶接構造用 圧延鋼新材 JIS G3106 SM490YB（以下，普 通鋼新材)，（2）溶接構造用耐候性熱間圧延 鋼新材 JIS G3114 SMA490BW（以下，耐候 性鋼新材), (3) 実橋梁から切り出した鋼材 で，グラインダーによりほぼ全面地鉄が出 るまでさび落とししたもの（以下，さび落 とし材)，(4)実橋梁から切り出した鋼材で さび付着のもの (以下，さび付着材）の 4 サ ンプルについて，エレクトロメーター（北 斗電工 (株)，HA-1510）を用いて測定を行 った。測定条件は，液静止，大気開放，室 温 $\left(25^{\circ} \mathrm{C}\right)$ とした。参照電極には飽和 $\mathrm{KCl}$ 中銀-塩化銀電極 (以下, $\mathrm{Ag} / \mathrm{AgCl}$ 電極) を 用いた。測定時間は 4 サンプルの電位が定 常値に達するまでとした。

\section{3. 結果および考察}

\section{1 腐食調查結果}

\section{1 .1 外観目視結果}

過去にも今回の報告と同じ室蘭新道などにおいて腐食 調査が行われており，その結果をもとに表面処理を施し た耐候性鋼材の健全度評価基準案が 2004 年に提案され ている ${ }^{4)}$ (以下，この 2004 年に提案された評価基準案を 2004 年度評価基準案と呼ぶ). 今回の腐食調査において も, 2004 年度評価基準案に準拠し, 外観目視評価を行っ た。ただし， 2004 年度評価基準案にある「被膜にさびが 見られない．または，被膜の下や中にわずかなさびが見 られる（評点 $\mathrm{A}, \mathrm{B}) 」$ 状態は，「腐食が進まず，薄いさび （評点 5)」と同じグループに分類した. 2004 年度評価基 準案では，被膜外観評価とさび外観評価が区別されてい るが, 評点 $\mathrm{A}, \mathrm{B}$ および評点 5 いずれの場合も, 腐食が進 まず健全な外観である点では共通であるため，今回の外 観目視評価では両者を同じグループに分類した。

また，今回の外観目視評価では，2004 年度評価基準案 にあるさび面積率を省略した。 さび面積率はさび外観評 価に付与される項目であり，さび面積率によって，さび 外観評点が変わるわけではない.さび面積率の違いがさ び外観評点に影響を及ぼさないこと, 後述する断面観察 結果から腐食状況とのあいだに相関が見られなかったこ とから, 今回の調査ではさび面積率を用いずに外観目視 評価を行った.

具体的には，外観目視によりさび外観を以下の 5 段階 評点で判定した。評点 5 は表面処理被膜が多く残ってい る，あるいは腐食が進まず薄いさびの場合，評点 4 は微 細で外観平均粒径 $1 \mathrm{~mm}$ 程度の均一なさびの場合, 評点 3 は微細で外観平均粒径が $1 \sim 5 \mathrm{~mm}$ 程度のさびの場合, 評点 2 は外観平均粒径 5 25 mm 程度のうろこ状さびが 生じている場合，あるいは硬いこぶ状さびが生じている 場合, 評点 1 は層状剥離が生じているさびの場合である. 2004 年度評価基準案に基づき，評点 5〜3 を「正常（normal)」, 評点 2 を「要観察 (care)」, 評点 1 を「異常 (critical)」と分類した. Fig. 2 に今回調查した箇所のう ち, 評点 5 から評点 1 のさび外観の一例を示す.

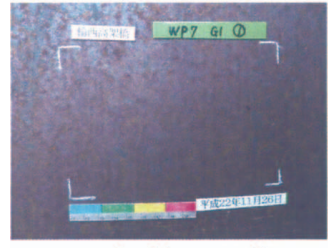

rank-5(normal)

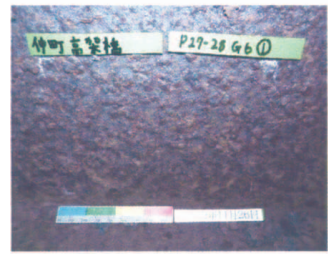

rank-2(care)

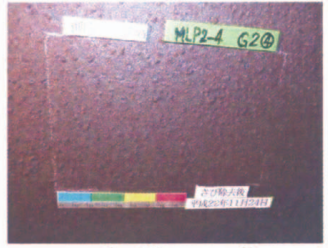

rank-4(normal)

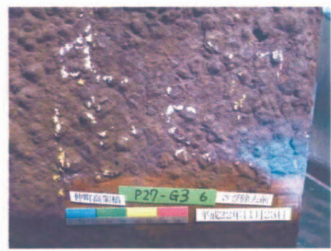

rank-1(critical)

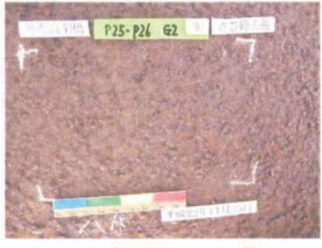

rank-3(normal)

Fig. 2 Appearances of rust formed on the weathering steel used for Muroran shindou. 
この判定基準に基づき, 今回調査した 78 力所のさび 外観評点の分布を Fig. 3 に示す. 調査した 78 カ所中, 57 力所は評点 3 以上の正常さびと判定された. 57 カ所の内 訳は桁中間部が 38 力所, 桁端部が 19 力所であった. 評 点 1 の層状剥離さびは 11 カ所であり, 桁中間部におい て 2 力所, 桁端部において 9 力所確認された。評点 1 の 層状剥離さびが桁端部において多く確認されたのは, 過 去に伸縮装置などから凍結防止剂を含んだ水が漏水して いたことに加えて, 日当りや風通しの悪さなどの環境条 件が重なったことで, 正常なさびが形成されなかったこ とが原因と推察される.なお今回の調査において確認さ れた評点 1 の層状剥離さびの箇所などについては, 必要 に応じて順次，止水対策や補修が行われているところで ある. 評点 2 のさびは桁中間部に 8 力所, 桁端部に 2 力 所確認され，桁中間部の方が多かった．桁中間部で確認 された評点 2 のさび 8 カ所のうち, 2 力所は外桁の下フ ランジ上面に発生したこぶ状さびであった。 また別の 2 カ所は本線に近接するランプ橋に存在したうろこ状さび であった。このうろこ状さびは, 本線を車が走行する際 に巻き上げられた凍結防止剤が付着したため発生したも のと考えられる. 残り 4 力所は中桁に発生したうろこ状 さびであり，これらは日当りや風通しが悪く湿潤環境が 長期にわたり保持されたために発生したものと推察され た.

\section{1 .2 さび・被膜厚}

Fig. 4 にさび・被膜厚と外観目視評点との関係を示す. Fig. 4 より, 外観評点が下がるにつれて, さび・被膜厚 が大きくなり，そのばらつきもまた大きくなる傾向を示 す. 例えば, 評点 5 のさび・被膜厚は $46 \sim 470 \mu \mathrm{m}$ の範 囲に分布するのに対し, 評点 1 のさび・被膜厚は 313〜 $1500 \mu \mathrm{m}$ 以上の範囲に分布した。 ただし，外観評点 1 で あるにも関わらず，さび・被膜厚が $600 \mu \mathrm{m}$ 以下と測定 された箇所も存在した。これらの箇所のさび外観を調べ てみると, いずれも層状剥離さびが脱落した箇所である ことが分かった。このため, 外観目視評点 1 であるにも 関わらず，さび・被膜厚が薄く測定されたものと思われ る.このような層状剥離さびが脱落したと思われる箇所 は, 今回調査した 78 地点のうち 3 地点存在した (Fig. 4 中, “delamination of rust” の 3 デー夕)。これら層状剥 離さびが脱落したと思われる 3 地点を除くと, さび・被

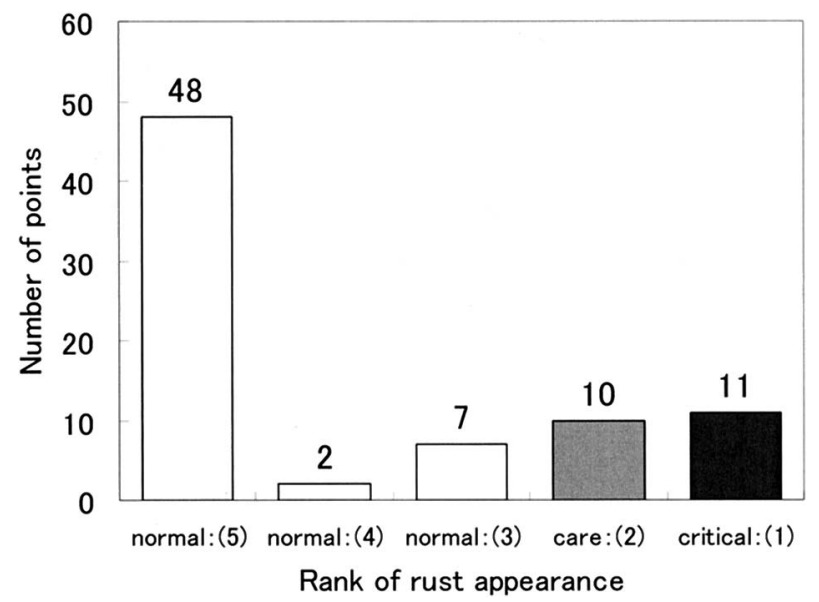

Fig. 3 Distribution histogram for rank of rust appearance.

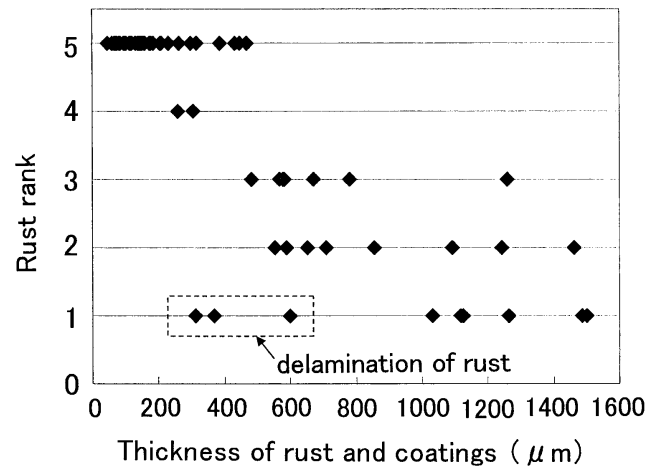

Fig. 4 Relationship between rust rank and thickness of rust and coatings.

膜厚と外観目視評点には，外観評点が下がるにつれてさ び・被膜厚が厚くなるという相関関係があることが分か った. Fig. 4 より, 評点 5,4 のさび・被膜厚はすべて 600 $\mu \mathrm{m}$ 未満であり, 評点 2,1 のさびは, 上記層状剥離さび が脱落したと思われる箇所を除くと約 $600 \mu \mathrm{m}$ 以上であ ることが分かる。このことから, さび・被膜厚 $600 \mu \mathrm{m}$ が要観察あるいは異常さび形成の目安となることが分か った。この $600 \mu \mathrm{m}$ のさび・被膜厚は，2004 年度評価基 準案においても, 正常と要観察とのしきい值とされてい る.今回実施したさび・被膜厚調査結果においても, 2004 年度評価基準案と同様に, $600 \mu \mathrm{m}$ が正常と要観察 を分けるさび・被膜厚となることが分かった。そこで， より適切に腐食状況を把握するため, 「3.1.1 外観目視 結果」記載のさび外観評点について, さび・被膜厚によ る補正 (さび・被膜厚 $600 \mu \mathrm{m}$ 以上の場合, 外観目視評点 が3〜 5 であっても評点 2 とする）を行うこととした。

\subsection{3 イオン透過抵抗値}

Fig. 5 にイオン透過抵抗值とさび ・被膜厚との関係を 示す. イオン透過抵抗值は最小で $0.180 \mathrm{k} \Omega$, 最大で 57.6 $\mathrm{M} \Omega$ あった. イオン透過抵抗值が異常腐食さび形成の目 安となる $3 \mathrm{k} \Omega^{6)}$ を下回ったのは 78 地点中 19 地点であ り, 残りの地点は $3 \mathrm{k} \Omega$ を上回った. イオン透過抵抗值 が低い地点のさび形態は, 評点 2 のうろこ状さびや評点 1 の層状剥離さびである場合が多かった.

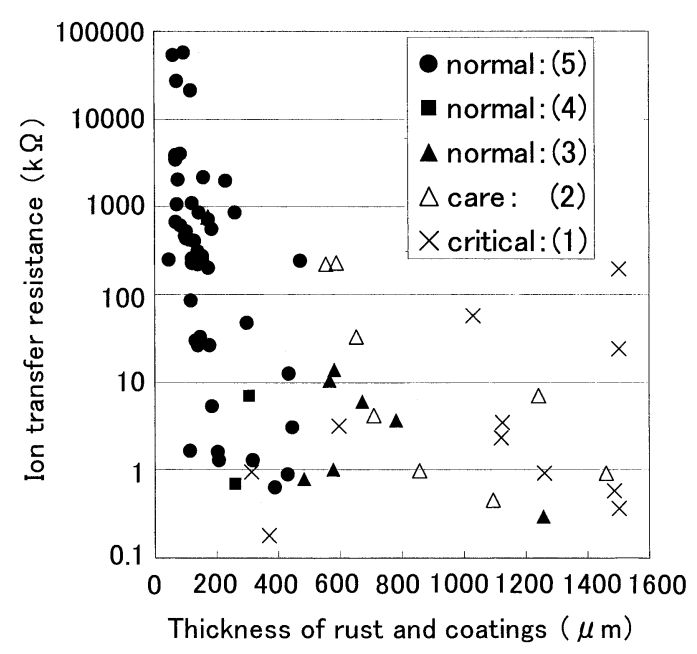

Fig. 5 Relationship between ion transfer resistance and thickness of rust and coatings. 


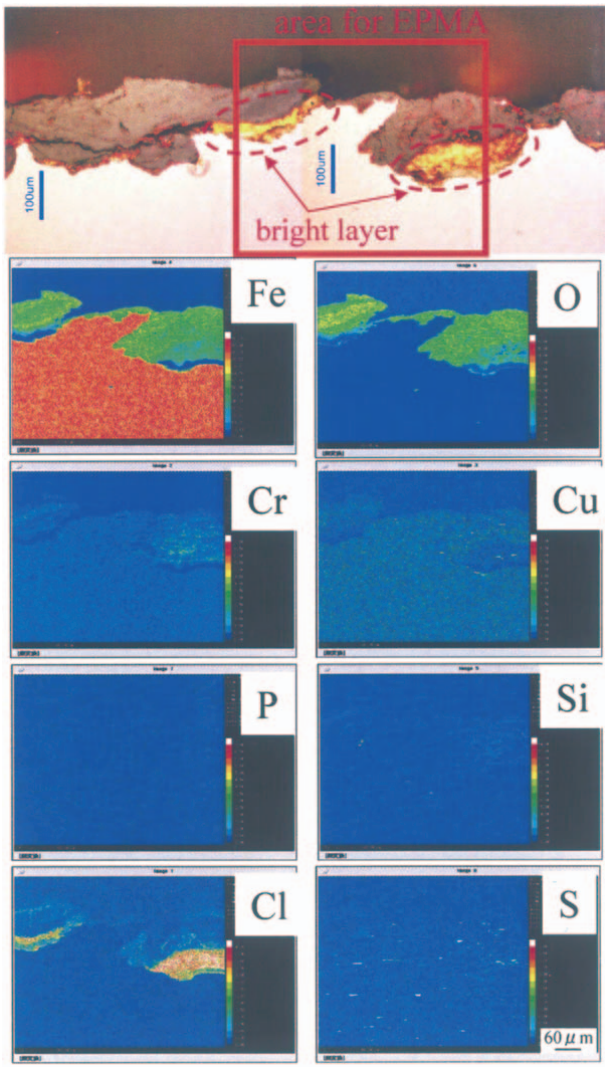

Fig. 6 Cross-sectional observation by reflected polarized light and EPMA analysis for the rust of rank-1.

\subsection{4 断面観察および EPMA 分析結果}

Fig. 6 に外観評点が 1 のコアサンプル断面観察および EPMA 分析結果を示す．偏光顕微鏡で観察した場合，一 般に保護性さびは消光し, 非保護性さびは偏光して見え るといわれる ${ }^{7)}$. Fig. 6 の偏光顕微鏡観察結果より，地鉄 界面付近に輝度の高い偏光層 (Fig. 6 中, “bright layer”) が存在しており，非保護性さびの形成が示唆される。ま た EPMA 分析の $\mathrm{Cl}$ 分布図から，この偏光層の箇所にお いて $\mathrm{Cl}$ が強く検出されていることが分かる．なお，表 面処理剤の成分である $\mathrm{P}, \mathrm{Si}$ はほとんど検出されておら ず，Fig. 6 に示す箇所では表面処理剤が消失しているこ とが分かる。

Fig. 7 に外観評点が 5 のコアサンプル断面観察および EPMA 分析結果を示す. Fig. 7 の偏光顕微鏡観察結果よ り，地鉄界面に保護性さびの存在を示唆する消光層 (Fig. 7 中, “dark layer”) が生成していることが確認された。 また EPMA 分析の P, Si の分布図から, 表面処理剂の成 分である $\mathrm{P}, \mathrm{Si}$ が連続して検出されていることが分かる. このことから架設から 30 年以上経過しても, 表面処理 剤の成分が残存している箇所もあることが判明した。

\section{2 自然浸漬電位経時変化}

Fig. 8 に $0.1 \mathrm{M} \mathrm{Na}_{2} \mathrm{SO}_{4}$ 溶液中における各試料の自然浸 漬電位の経時変化を示す. 耐候性鋼新材を除き, 電位は 時間の経過とともに徐々に卑化する挙動を示した。耐候 性鋼新材の電位は浸漬開始から 45 分後までは上昇し, そ の後他の試料と同様に卑化する傾向を示した。定常值に 達したと思われる 5 時間後の各試料の電位を比較すると,

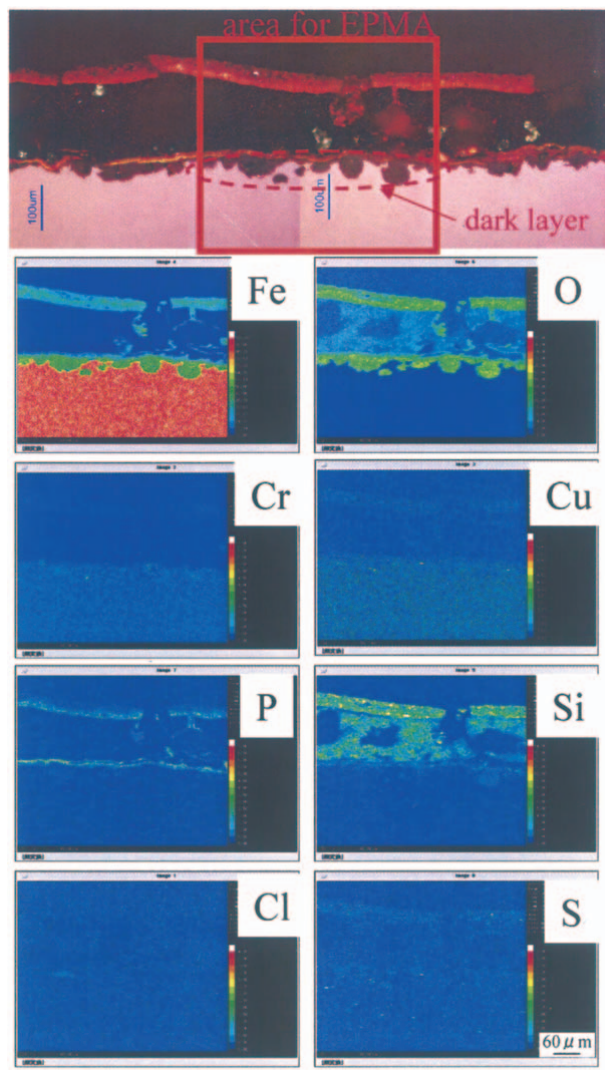

Fig. 7 Cross-sectional observation by reflected polarized light and EPMA analysis for the rust of rank -5 .

貴な方からさび付着材 $(-0.57 \mathrm{~V})>$ 耐候性鋼新材 $(-0.63$ $\mathrm{V})$ =さび落とし材 $(-0.63 \mathrm{~V}) \doteqdot$ 普通鋼新材 $(-0.64 \mathrm{~V})$ と なった。さび付着材以外の 3 種（普通鋼新材，耐候性鋼 新材, さび落とし材）の安定時の電位はほぼ等しくなる ことが分かった. 鹿島ら ${ }^{8)}$ は 32 年間大気曝露された裸仕 様耐候性鋼橋梁から切り出したサンプルの電位測定を $0.1 \mathrm{M} \mathrm{Na}_{2} \mathrm{SO}_{4}$ 溶液中で行っており, さび層の保護性評価 として, $-0.3 \mathrm{~V}$ (vs.SCE) 以上の貴な電位を示すさび層 は耐候性に優れるとの結果を得ている。今回測定したさ び付着材の電位は, 浸漬直後の最大值においても $-0.4 \mathrm{~V}$ （vs.SCE）であり，保護性さび形成の基準となる電位より 低かった。これは今回切り出したサンプルが 3.1.1の外 観目視評点で 1 となる層状剥離さびを有しており，保護

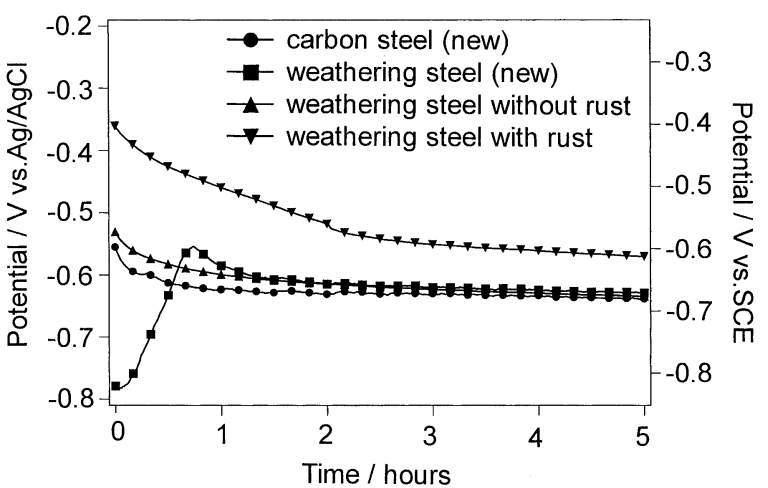

Fig. 8 Changes of potential with immersion time for the carbon and weathering steels in $0.1 \mathrm{M} \mathrm{Na}_{2} \mathrm{SO}_{4}$ solution. 
性さびが形成されていなかったためと考えられる.

\section{4. 結}

架設から 30 年以上が経過した表面処理仕様耐候性鋼 橋梁の腐食調査を行った。外観目視結果より, 調査した 78 地点中 57 地点は評点 3 以上の正常さびと判断された. 11 地点で評点 1 の層状剥離さびが生じており, その原因 は桁端部における凍結防止剂を含んだ水の漏水に加え て, 日当たり, 風通しなどの環境条件が重なったことに よるものと推察された。さび・被膜厚と外観目視評点に は相関があり，外観評点が下がるにつれてさび・被膜厚 は大きくなる傾向を示した。今回の調査では, さび・被 膜厚 $600 \mu \mathrm{m}$ を正常さびと要観察さびのしきい值とした. EPMA 分析結果より, 評点 1 のさびには地鉄との界面に $\mathrm{Cl}$ の濃縮が確認され, 評点 5 のさびでは地鉄との界面に 保護性さびが存在し，表面処理被膜成分が残存している ことが判明した。実橋梁から切り出した層状剥離さびを 有する耐候性鋼材の電位は, 未使用の耐候性鋼材の電位 よりも高い值を示すものの, 保護性さび形成の基準とな る電位よりは低い值となった。

\section{参 考 文 献}

1) K. Shiotani, W. Tanimoto, C. Maeda, F. Kawabata and K. Amano, Zairyo-to-Kankyo, 49, 67 (2000).

2) H. Fujiwara, T. Sugano, M. Aosawa and T. Nagatani, Zairyo-to-Kankyo, 49, 88 (2000).

3) M. Yamashita, K. Asami, T. Ishikawa, T. Ohtsuka, H. Tamura and T. Misawa, Zairyo-to-Kankyo, 50, 521 (2001).

4) Independent Administrative Institution Civil Engineering Research Institute of Hokkaido, Japan Association of Bridge Eng., Japan Iron and Steel Federation, Report on Investigation of Inspecition Standard for Unpainted Weathering Steel Bridge (2004).

5) Public Work Research Institute -Ministry of Construction, The Kozai Club and Japan Association of Steel Bridge Construction, Report on Application of Weathering Steel to Highway Bridges (XX), No.88 (1993).

6) H. Kihira, Zairyo-to-Kankyo, 48, 697 (1999)

7) H. Okada, Y. Hosoi, K. Yukawa and H. Naito, Tetsu-toHagane, 5, 11 (1969)

8) K. Kashima, S. Hara, H. Kishikawa and H. Miyuki, Zairyoto-Kankyo, 49, 15 (2000).

(Manuscript received October 31, 2011; in final form February 13, 2012)

\section{要 旨}

架設から 30 年以上経過した表面処理仕様耐候性鋼橋梁の腐食を調査するため，外観目視調査，さび • 被膜厚測定，イオン透過抵抗測定，偏光顕微鏡による断面観察，EPMA 分析を実施した。外観目視調査で は 78 力所中 57 力所が正常と判断された。橋梁桁端部の漏水が生じていた箇所において，うろこ状さびや 層状剥離さびが観察される場合があった。さび外観評点が下がるにつれて，さび・被膜厚は厚くなる傾向 があった．断面観察および EPMA 分析より，異常さびの底面には濃縮した $\mathrm{Cl}$ が存在し，正常さびの底面 には保護性さびと思われる消光層が存在することが判明した.

キーワード耐候性鋼橋梁，腐食調査，表面処理，さび・被膜厚，イオン透過抵抗，腐食電位， EPMA 